\title{
Current trends and future directions in teaching English pronunciation
}

\author{
Afshari, Sajad $\triangle$ \\ University of Isfahan, Iran (afshari.sajad@yahoo.com) \\ Ketabi, Saeed \\ University of Isfahan, Iran (s.ketabi@yahoo.com)
}

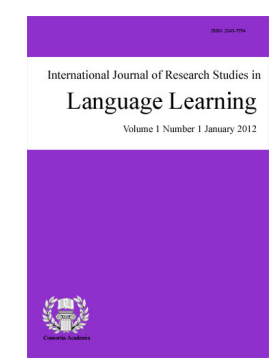

ISSN: $2243-7754$

Online ISSN: 2243-7762

Received: 2 February 2016

Available Online: 15 May 2016

\begin{abstract}
Though pronunciation pedagogy went through drastic fluctuations until mid-1980s, since then the overall attitude towards its role and instructional prominence as a potent and essential communicative element has remained consistent. Developing functional intelligibility, communicability, increased self-confidence, the development of speech monitoring abilities and speech modification strategies for use beyond the classroom have been its the main goals. Nowadays, pronunciation pedagogy seems to be adopting a more humanistic orientation by taking into consideration some affective variables derived from psychology and neuro-linguistics programming (NLP). This paper emphasizes the need for teaching pronunciation to gain full communicative competence and the importance of incorporating the findings of other disciplines, such as psychology, NLP, technology as well as socio-psychological issues including identity, ego boundary or interpersonal relationships in pronunciation teaching.
\end{abstract}

Keywords: pronunciation pedagogy; intelligibility; current trends 


\section{Current trends and future directions in teaching English pronunciation}

\section{Introduction}

The importance of pronunciation in successful communication has been emphasized by many researchers. Fraser (2000), for instance, argues that:

Being able to speak English of course includes a number of sub-skills, involving vocabulary, grammar, pragmatics, etc. However, by far, the most important of these skills is pronunciation; with good pronunciation, a speaker is intelligible despite other errors; with poor pronunciation, a speaker can be very difficult to understand despite accuracy in other areas. Pronunciation is the aspect that most affects how the speaker is judged by others, and how they are formally assessed in other skills (p. 7).

According to Gilner (2008, p. 93), "pronunciation is an integral aspect of communicative competence (Morley, 1991) that can influence the desire to use the language (Guiora, 1972) as well as the quantity and quality of input received and output produced (Fraser, 2002)". Brown (1991) maintains that "no one would deny the importance of pronunciation as a contributor towards learners' proficiency in English" (p. 1), and that "learners are clearly aware that poor pronunciation represents a considerable barrier to their success in English" (p. 1). For Madden and Moore (1997, p. 3), "pronunciation is the most obvious and unavoidable marker of a language learner's proficiency", and for MacDonald (2002, p. 3), "pronunciation is a key element of the learning of oral skills in a second language". Derwing, Rossiter, and Munrol (2002), refer to the fact that pronunciation accuracy may also help escalate one's social status since speaking with a foreign accent may be degraded and stigmatized by native speakers and, therefore, ESL/EFL learners may forfeit their true standing and thus, result in social and/or professional discrimination. While there is a debate among those who favor teaching pronunciation and those who are against teaching pronunciation, most language teaching experts would agree that comprehensible pronunciation is a common feature among all successful language learners, and intelligible/comprehensible pronunciation is deemed to be necessary for each and every user of the target language (Zemanova, 2007). Furthermore, some researchers (e.g., Gilbert, 2008; Schwartz, Markoff, \& Jain, 1991; Thompson, Taylor, \& Gray, 2001; Wrembel, 2001) have stressed the importance of incorporating the findings of other disciplines such as psychology, neurolinguistics, technology, and multiple intelligence in teaching English pronunciation.

\section{Current issues in pronunciation teaching}

\subsection{Shift of focus from teaching and teachers to learning and learners}

There has been a prominent shift within the field of language teaching and learning with greater emphasis being put on learners and learning rather than on teachers and teaching over the last twenty years. In parallel to this new shift of interest, a move from specific linguistic competencies to broader communicative competencies has emerged as goals for teachers and students (Morley, 1991). The need for the integration of pronunciation with oral communication, a change of emphasis from segmentals to suprasegmentals, more emphasis on individual learner needs, meaningful task-based practices, development of new teacher strategies for the teaching and introducing peer correction and group interaction were emphasized within the field of pronunciation teaching (Castillo, 1991). Research has revealed that the teaching of segmental phonemes isn't enough for intelligibility in communication (Cohen, 1977).

Traditionally the emphasis of instruction was on specific linguistic competencies but, more recently this focus has changed to broader communicative competencies. Further, it is important to recognize that for many 
learners "the development of improved L2 pronunciation remains a primary goal" (MacDonald, Yule, \& Powers. 1994, p. 76). Thus, pronunciation should play an important role in any language learning experience.

Morley (1991) identified 7 significant changes in theoretical paradigms - in learning models, linguistic models, and instructional models - that inform much of the state-of-the-art work in the field today:

$>\quad$ From a language learning perspective of "outside in", to one of "inside out"; that is, a new concept of language acquisition that views the learner as the active prime mover in the learning process.

$>\quad$ Following from this altered conceptualization of the learning process, a movement from a focus on the group, to an increasing focus on individual learner differences and individual learning styles and strategies.

$>\quad$ From a focus on language as simply a formal system, to a focus on language as both a formal system and a functional system, one that exists to satisfy the communicative needs of its users.

$>$ From linguistic preoccupation with sentence-level grammar to a widening interest in semantics, pragmatics, discourse, and speech act theory.

$>$ From an instructional focus on linguistic form and correct usage to one on function and communicatively appropriate use.

$>$ From an orientation of linguistic competence to one of communicative competence.

$>$ From a global-competence concept to a set of detailed competency specifications and the introduction of an especially useful model that brings together a number of viewpoints in one linguistically oriented and pedagogically useful frame work: (a) grammatical competence, (b) sociolinguistic competence, (c) discourse competence, and (d) strategic competence.

These developments have led to a wide variety of changes in virtually all aspects of ESL/EFL, including the area of pronunciation teaching. For example, pronunciation could no longer be taught merely as a set of rules but instead as part of an overall system of communication.

\subsection{Intelligibility vs. nativeness}

Pronunciation research and pedagogy have long been influenced by two contradictory principles; the nativeness principle and the intelligibility principle. The nativeness principle holds that it is both possible and desirable to achieve native-like pronunciation in a foreign language. The nativeness principle was the dominant paradigm in pronunciation teaching before the 1960s, but its influence was rapidly diminished by research showing that nativeness in pronunciation appeared to be biologically conditioned to occur before adulthood (Lenneberg, 1967; Scovel, 1995), leading to the logical conclusion that aiming for nativeness was an unrealistic burden for both teacher and learner. Despite extensive ongoing research into a critical period for acquiring pronunciation, in practice very few adult learners actually achieve native-like pronunciation in a foreign language. Factors such as motivation, amount of first language (L1) use, and pronunciation training are positively correlated with more native-like pronunciation, but none of these other factors seems to overcome the effects of age (Flege \& Frieda, 1995; Moyer, 1999). Furthermore, 'perfect' or near-native pronunciation raises the question of which target model is to be used, be it British English, Australian English, etc. Whichever model is chosen, such a level is virtually unattainable for many learners and also "not a necessary condition for comprehensible communicative output." (Morley, 1991, p. 498). Further, such a level may not be desirable to the learner who wants to keep their L1 identity.

The intelligibility principle implies that different features have different effects on understanding. Instruction should focus on those features that are most helpful for understanding and should deemphasize those that are relatively unhelpful (Levis, 2005). According to Morley (1991, p. 488), "Intelligible pronunciation is an 
essential component of communication competence". For this reason, teachers should incorporate pronunciation into their courses and expect students to do well in them. Teachers should pay attention to reassessing learner needs and learners' goals, instructional objectives, and learning / teaching methodologies. They should attach importance to current directions in language learning and teaching theory and pedagogy. They should be primarily concerned with how pronunciation fits into communicative language teaching. Intelligibility means whether an utterance is understood by an interlocutor or not. It is often measured by having listeners transcribe utterances (Munro \& Derwing, 1995).

Indeed, intelligibility is the degree to which a listener can understand what is being said or in the words of Kenworthy (1987) "intelligibility is being understood by a listener at a given time in a given situation" (p. 13). In recent years, investigations have been conducted to assess how various aspects of pronunciation make contributions to intelligibility. For example, prosodic features play an important role in both accent ratings and intelligibility scores (Anderson-Hsieh, Johnson, \& Koehler, 1992; Munro \& Derwing, 1995). More specifically, primary sentence stress (Hahn, 2004), word stress (Field, 2005; Zielinski, 2008) and speaking rate (Munro \& Derwing, 2001) affect intelligibility. As for segments, some consonants and vowels have more importance or a higher functional load than others (Catford, 1987; Munro \& Derwing, 2006) and are thus more critical to comprehensibility. Thornbury (2008) also agrees that intelligibility is more important in English pronunciation. To him "intelligibility (i.e. being understood) is more important than sounding like a native speaker". He also suggests that while teaching, teachers should give special attention to pronunciation whether it is intelligible, receptive, in context, teachable etc. (p 162). Penny Ur (1996) notifies that the aim of the pronunciation is not to achieve a perfect imitation of native accent, but simply to get the learner to pronounce accurately enough to be easily and comfortably comprehensible to other speakers.

There should be emphasis on meaningful communication when teaching pronunciation to the students. Without adequate pronunciation skills, the learner's ability to communicate is severely limited. Morley (1991, p. 489) states that not attending to a student's pronunciation needs, "is an abrogation of professional responsibility".

\subsection{Identity and pronunciation}

Accent is influenced not only by biological timetables but also by sociolinguistic realities. In other words, speakers speak the way they do because of the social groups they belong to or desire to belong to. The role of identity in accent is perhaps as strong as the biological constraints. Accent, along with other markers of dialect, is an essential marker of social belonging. The pull of identity is also strong for NNSs of a language. Jenkins (2000) describes how same-L1 NNS pairs pronounce English with a greater number of deviations than do pairs of speakers from different L1s. This tendency toward convergence, even when it means speaking English with more deviant pronunciation, indicates the importance of identity. Gatbonton, Trofimovich, and Magid (2005) try to clarify how ethnic group affiliation is a critical factor in pronunciation accuracy. They argue that inaccuracy may reflect neither lack of ability nor interest but rather social pressure from home communities nor other students who speak their L1. In fact, speakers who are too accurate risk being seen as disloyal to their primary ethnic group.

\subsection{Interdependence of pronunciation and other skills}

Gilbert (1984) contended that the skills of listening comprehension and pronunciation are interdependent. If learners cannot hear English well, they are cut off from the language. If they cannot be understood easily, they are cut off from conversation with native speakers. Noteboom (1983) also has suggested that speech production is affected by speech perception; the hearer has become an important factor in communication discourse. This shows the need to integrate pronunciation with communicative activities; to give the student situations to develop their pronunciation by listening and speaking. The current research and the current trend reversal in the thinking of pronunciation exhibits there is a consensus that a learner's pronunciation in a foreign language needs to be taught in parallel to the communicative practices for the learner to be able to communicate effectively with 
native speakers (Otlowski, 1998). According to Levis and Grant (2003), pronunciation should be a part of a speaking and listening class, and yet it often isn't.

\subsection{Pronunciation and focus on form}

Today, pronunciation issues can be dealt with as they arise following an incidental focus-on-form approach in the communicative classroom. As Hardison (2010) puts it, teachers can also choose vocabulary and pedagogic tasks that would seed the content of a lesson with a particular segmental or suprasegmental issue (e.g., intonation in questions); in doing so, it would be presented and practiced in contextualized meaningful communication.

From a theoretical perspective, some second language acquisition researchers assume that recasts can simultaneously provide both positive and negative evidence without compromising communicative flow. This allows for second language learners to make cognitive comparisons between their non-target-like forms and target-like reformulations during meaningful discourse (Long, 2007). Other researchers, however, have argued that recasts might not be the most effective type of feedback, at least for the development of L2 morphosyntax, because it has been contentious to what degree learners can succeed in perceiving the negative evidence presented in recasts (Lyster, 2007). With respect to L2 pronunciation errors, however, the corrective intention of recasts as negative evidence is unambiguous. Several observational studies have found that learners tend to generate more successful repairs following pronunciation-focused recasts than morphosyntax-focused recasts, and to perceive the corrective intention of these recasts. In adult EFL classrooms, Sheen (2006) noted that although pronunciation-focused recasts occurred much less frequently (21.0\% of the total number of recasts) than morphosyntax-focused recasts $(51.5 \%)$, students repeated the former with a higher rate of successful repair $(91.8 \%)$ than the latter $(70.8 \%)$.

\subsection{Autonomous pronunciation learning}

In parallel to the emergence of autonomous language learning, many innovative pronunciation teachers have attempted to move towards autonomous pronunciation learning. Such teachers motivate their students to become autonomous learners. Since students cannot always find the chance to ask their language teacher for help in real life contexts, they should be stimulated to come to a stage where they can make their own decisions about their own pronunciation learning. Students can be actively involved in their own learning. If the teacher teaches the students how to transcribe words by using phonetic symbols, students become autonomous to some extent in that they may look up their monolingual dictionaries when not knowing how to pronounce a word in the target language. Moreover, motivating students to use computer-assisted pronunciation teaching programs can lead to autonomous pronunciation learning and hence may contribute to the improvement of the pronunciation of the students in the target language. However, it should not be forgotten that students are semi-autonomous pronunciation learners since it is the language teacher who selects the most appropriate computer-assisted pronunciation teaching program relevant to the needs and expectations of an individual student (Hismanoglu 2004).

\section{The impact of other disciplines on pronunciation}

\subsection{Technology}

There has recently been an increasing interest in the use of technology for the teaching of pronunciation. Various types of computer hardware have been introduced and a number of studies show a growing interest among language teachers and researchers in the benefits of computer assisted pronunciation pedagogy (Albertson, 1982; Chun, 1989; Molholt, 1988; Molholt, Lane, Tanner, \& Fischer, 1988; Pennington, 1988; Perdreau \& Hessney, 1990). Many empirical studies have stressed the effectiveness of this technology in second/foreign language pronunciation teaching (de Bot, 1983; Dunkel \& Rekart, 1991; Johnson, Schwartz, Markoff, \& Jain, 1991; Richmond, 1976; Vardanian, 1964; Weltens \& de Bot, 1984). Because Computer Assisted 
Afshari, S., \& Ketabi, S.

Pronunciation Teaching provides students with a private, stress-free environment within which they can access virtually unlimited input, practice at their own pace and receive instantaneous feedback through the integration of Automatic Speech Recognition, it can be accepted to be beneficial to second/foreign language learning (Hismanoglu, 2006).

\subsection{Psychology}

The impact of the discipline of psychology can be seen in current trends in pronunciation teaching. Since pronunciation is very sensitive to emotional factors (Brown, 1995) and that its nature is strongly related to students' ego, identity and the level of self-confidence, new trends in teaching pronunciation put a strong emphasis on the affective domain of learning to counterbalance the traditional focus placed exclusively on intellectual learning. An ideal receptive learning state comes into being when a student is physically relaxed, emotionally calm and mentally alert. Research findings show that a relaxed frame of mind and a degree of confidence pave the way for a correct production of target language sounds. Hence, establishing a non-threatening student-friendly environment is amongst main concerns of modern pronunciation instruction. Efficient ways of reducing stress related with pronunciation practice and dealing more efficiently with learners' emotions are based on the use of drama techniques. It is through drama techniques that learners become more expressive and more willing to experiment with sounds or intonation patterns. A commonly used strategy involves assuming an English or American identity and putting on a strong native accent, as if becoming a different dramatic persona (Wrembel, 2001). Gilbert (2008) refers to psychological factors in pronunciation and contends that:

There are also psychological factors that affect the learning of pronunciation in ways that are not so true of studying grammar or vocabulary. For one thing, the most basic elements of speaking are deeply personal. Our sense of self and community are bound up in the speech-rhythms of our first language (L1). These rhythms were learned in the first year of life and are deeply rooted in the minds of students. Therefore, it is common for students to feel uneasy when they hear themselves speak with the rhythm of a second language (L2). They find that they "sound foreign" to themselves, and this is troubling for them. Although the uneasiness is usually unconscious, it can be a major barrier to improved intelligibility in the L2. A teacher can help overcome this psychological barrier and other challenges by thinking of the goal of pronunciation instruction not as helping students to sound like native speakers but as helping them to learn the core elements of spoken English so that they can be easily understood by others. In other words, teachers and students can overcome the frustrations, difficulties, and boredom often associated with pronunciation by focusing their attention on the development of pronunciation that is "listener friendly." After all, English pronunciation does not amount to mastery of a list of sounds or isolated words. Instead, it amounts to learning and practicing the specifically English way of making a speaker's thoughts easy to follow (p. 1).

\subsection{Neurolinguistics programming}

Neurolinguistic programming is another perspective frequently advocated by innovative pronunciation teachers since it deals efficiently with affective factors concerning learning pronunciation and facilitates an accurate production of target language sounds. NLP is a collection of patterns and strategies based on a series of underlying understandings of how the mind works and how people act and react. NLP's main concern is neurological processes called states. According to NLP perspective, a desired state of mind, when learning occurs naturally, could be induced through relaxation techniques such as breathing exercises or autogenic training (i.e. guided imagery activities), which render learners emotionally calm and mentally alert and, at the same time, help break down their ego boundaries.

The NLP perspective gives much prominence to the role of interpersonal relationships between the teacher 
and the learner. This meta-communication, i.e. rapport, linkage and authority, is believed to be especially conducive to success in pronunciation learning. The process of learning pronunciation of a second language has been demonstrated to be especially sensitive to suggestion. Sometimes referred to as educational hypnosis, suggestion is one of key priorities in NLP. It can be defined as a desire to constantly suggest internal representations that lead someone to facilitative states. Thus, the way teachers talk about acquiring good pronunciation and the messages sent consciously or subconsciously to students include significant suggestive communication patterns. NLP contributes to use language more efficiently so that through sending positive messages and suggestions of success we can generate intended responses (Wrembel 2001, p. 3).

\subsection{Multiple modalities and Howard Gardner's Multiple Intelligence}

In recent years, the idea of approaching pronunciation teaching from different modalities (i.e. auditory, visual, kinesthetic, tactile) has become very popular within the field of foreign language teaching. To present and practice a sound from several perspectives is just basic stuff of good pronunciation teaching. Language teachers should employ a multi-modal method in the pronunciation class; that is, every sound process should be taught as a totality: visual + auditory + kinesthetic + tactile (though not necessarily in that order). Thus, students can have the chance to strengthen their lesser modalities. For instance, any experienced pronunciation teacher knows that to produce / $\mathrm{r} /$ and / $1 /$ well may require all modalities be engaged and sequenced. Students should hear the distinction, feel the difference, consciously focus on the movement of lips and tongue, and probably focus on the place(s) where the tongue comes into contact with the palate (Acton 1997).

Whether there is a sound relationship between effective foreign language pronunciation teaching and Howard Gardner's (1983) Multiple Intelligences Theory has been the primary concern of some researchers. Some researchers have offered various pronunciation teaching techniques and activities related with each intelligence type included within the theory. For example, Thompson, Taylor, and Gray (2001) present various pronunciation teaching techniques and activities so as to help students develop effective target language pronunciation. For example, for students with bodily/kinesthetic intelligence, techniques like tossing a ball, using a rubber band, knee bending/body language, balloon squealing, etc. can be useful. Another example is related to students with visual/spatial intelligence, techniques like using wall charts, using a mirror, card games, and many others can be used. Moreover, for students with musical/rhythmic intelligence, techniques like using a song, using kazoos and using musical notation may be utilized by the teacher.

\section{Conclusion}

Recently, with intelligibility and comprehensibility being the prime goals of pronunciation teaching, technological developments as well as the influence of other disciplines such as psychology, neuro-linguistic programming, and multiple intelligences, the field of pronunciation teaching and learning has witnessed a renewed interest from the researchers and practitioners alike. However, although nowadays majority of SLA researchers and practitioners have agreed on the significant role of pronunciation as an essential part of communication, it has not yet received the importance it deserves and there is a lack of systematicity and consensus as to the inclusion and incorporation of the new developments in the real EFL/ESL classrooms. This is reflected in Isaacs' (2009) contention that "although pronunciation is considered part of linguistic form in the literature on form-focused instruction, it has been paid little more than lip service by many SLA researchers, who have tended to focus on grammar (p. 9)."

Various new developments in the field of pronunciation teaching presented in this paper share a number of characteristic features. Today, this field is considered an interdisciplinary approach that takes into consideration the role of affective factors and neuro-linguistics programming, appeals to different senses, takes advantage of technology, integrates pronunciation teaching with listening and speaking skills, and makes effective use of socio-psychological issues such as identity, ego boundary or interpersonal relationships. In other words, it seems that pronunciation teaching is taking a more humanistic orientation. By taking advantage of these findings and 
Afshari, S., \& Ketabi, S.

informing teachers of the latest developments in the field, learners' pronunciation needs and problems in EFL/ESL contexts can be more effectively dealt with. Furthermore, teachers can involve their learners intellectually, affectively, and physically in the process of learning pronunciation making it more effective and interesting. Last but not least, pronunciation in a foreign language needs to be taught in parallel to the communicative practices for the learner to be able to communicate effectively with native speakers.

\section{References}

Anderson-Hsieh, J., Johnson, R., \& Koehler, K. (1992). The relationship between native speaker judgments of nonnative pronunciation and deviance in segmentals, prosody, and syllable structure. Language Learning, 49(4), 529-555. http://dx.doi.org/10.1111/j.1467-1770.1992.tb01043.x

Brown, A. (Ed.) (1991). Teaching English pronunciation. A book of readings. London: Routledge.

Brown, H. D. (2001). Teaching by principles: An interactive approach to language pedagogy ( $2^{\text {nd }}$ ed.). NY: Longman.

Castillo, L. (1991). 'L2 Pronunciation pedagogy: Where have we been? Where are we headed?' The Language Teacher, 14(10), 3-7.

Catford, J. C. (1987). Phonetics and the teaching of pronunciation: A systemic description of English phonology. In J. Morley (Ed.), Current perspectives on pronunciation: Practices anchored in theory (pp. 87-100). Washington, DC: TESOL.

Cohen, A. (1977). Redundancy as a tool in listening comprehension, Listening comprehension in foreign language teaching: Research and classroom applications. TESOL Quarterly, 16(1), 71-77.

Derwing, T. M., Rossiter, M. J., \& Munro, M. J. (2002). Teaching native speakers to listen to foreign-accented speech. Journal of Multilingual and Multicultural Development, 23, 245-259. http://dx.doi.org/10.1080/01434630208666468

Field, J. (2005). Intelligibility and the listener: The role of lexical stress. TESOL Quarterly, 39, 399-423. http://dx.doi.org/10.2307/3588487

Flege, J., \& Freida, E. (1995). Amount of native-language (L1) use affects the pronunciation of an L2. Journal of Phonetics, 25, 169-186. http://dx.doi.org/10.1006/jpho.1996.0040

Fraser, H. (2000). Coordinating improvements in pronunciation teaching for adult learners of English as a second language. Canberra, Australia: University of New England.

Fraser, H. (2002). Change, challenge and opportunity in pronunciation and oral communication. Plenary Address at English Australia Conference, Canberra, October 2002. Retrieved from http://wwwpersonal.une.edu.au/ hfraser/documents/HFChangeChallengeOpp.pdf

Gardner, H. (1983). Frames of mind: The theory of multiple intelligences. New York: Basic.

Gatbonton, E., Trofimovich, P., \& Magid, M. (2005). Learners' ethnic group affiliation and L2 pronunciation accuracy: A sociolinguistic investigation. TESOL Quarterly, 39(3), 489-511. http://dx.doi.org/10.2307/3588491

Gilbert, J. (1984). Clear speech. Pronunciation and listening comprehension in American English. Student's book. Cambridge: CUP.

Gilbert, J. (2008). Teaching pronunciation: Using the prosody pyramid. Retrieved from www.cambridge.org/gb/elt/satellite_page/item2493274/Teacher-Support-Plus/?site_locale=en_GB

Gilner, L. (2008). Pronunciation: A review of methods and techniques. Nagoya University of Foreign Studies. Journal of the School of Foreign Languages, 35, 93-108.

Hahn, L. (2004). Primary stress and intelligibility: Research to motivate the teaching of suprasegmentals. TESOL Quarterly, 38(2), 201-223. http://dx.doi.org/10.2307/3588378

Hardison, D. M. (2010). Trends in teaching pronunciation. Retrieved from http://clear.msu.edu/clear/files/2213/6000/8128/fall2010.pdf

Hismanoglu, M. (2006). Current perspectives on pronunciation learning and teaching. Journal of Language and Linguistic Studies, 2(1), 10-108.

Isaacs, T. (2009). Integrating form and meaning in L2 pronunciation instruction. TESL Canada Journal, 27(1), 
1-12. http://dx.doi.org/10.18806/tesl.v27i1.1034

Jenkins, J. (2000). The Phonology of English as an international language. Oxford: Oxford University Press.

Kenworthy, J. (1987). Teaching English pronunciation. Harlow, U. K.: Longman.

Lenneberg, E. H. (1967). Biological foundations of language. New York: Wiley.

Levis, J. M. (2005). Changing contexts and shifting paradigms in pronunciation teaching. TESOL Quarterly, 39(3), 369-377. http://dx.doi.org/10.2307/3588485

Levis, J. M., \& Grant, L. (2003). Integrating pronunciation into ESL/EFL classrooms. TESOL Journal, 12(2), 13-19. http://dx.doi.org/10.1002/j.1949-3533.2003.tb00125.x

Long, M. H. (2007). Problems in SLA. Mahwah, NJ: Lawrence Erlbaum.

Lyster, R. (2007). Learning and teaching languages through content: A counterbalanced approach. Amsterdam: John Benjamins. http://dx.doi.org/10.1075/11lt.18

MacDonald, D., Yule, G., \& Powers, M. (1994). Attempts to improve English L2 pronunciation: The variable effects of different types of instruction. Language Learning, 44(1), 75-100. http://dx.doi.org/10.1111/j.1467-1770.1994.tb01449.x

MacDonald, S. (2002). Pronunciation: Views and practices of reluctant teachers. Prospect, 17(3), 3-18.

Madden, M., \& Moore, Z. (1997). ESL students' opinions about instruction in pronunciation. Texas Papers in Foreign Language Education, 3(1), 15-32.

Morley, J. (1991). The pronunciation component in teaching English to speakers of other languages. TESOL Quarterly, 25(3), 481-520. http://dx.doi.org/10.2307/3586981

Moyer, A. (1999). Ultimate attainment in L2 phonology: The critical factors of age, motivation and instruction. Studies in Second Language Acquisition, 21, 81-108. http://dx.doi.org/10.1017/s0272263199001035

Munro, M. J., \& Derwing, T. M. (1995). Foreign accent, comprehensibility, and intelligibility in the speech of second language learners. Language Learning, 45(1), 73-97. http://dx.doi.org/10.1111/j.1467-1770.1995.tb00963.x

Munro, M. J., \& Derwing, T. M. (2001). Modeling perceptions of the accentedness and comprehensibility of L2 speech: The role of speaking rate. Studies in Second Language Acquisition, 23, 451-468.

Munro, M. J., \& Derwing, T. M. (2006). The functional load principle in ESL pronunciation instruction: An exploratory study. System, 34, 520-531. http://dx.doi.org/10.1016/j.system.2006.09.004

Noteboom, S. (1983). Is speech production controlled by speech perception? In V.D. Broecke et al. (Eds.), Sound structure: Studies for Antonie Cohen (pp. 183-94). Foris: Dordrecht. http://dx.doi.org/10.1515/9783110846270.183

Otlowski, M. (1998). "Pronunciation: What are the expectations?" The Internet TESL Journal, 4(1). Retrieved from http://itesl.org/Articles/OtlowskiPronunciation.html

Scovel, T. (1995). Differentiation, recognition, and identification in the discrimination of foreign accents. In J. Archibald (Ed.), Phonological acquisition and phonological theory (pp. 169-181). Hillsdale, NJ: Lawrence Erlbaum.

Sheen, Y. (2006). Exploring the relationship between characteristics of recasts and learner uptake. Language Teaching Research, 10, 361-392. http://dx.doi.org/10.1191/1362168806lr203oa

Thompson, S., Taylor, K., \& Gray, H. (2001). Pronunciation with an eye on multiple intelligences. Paper presented in the WATESOL Convention Fall 2001.

Thornbury, S. (2008). CELTA. Cambridge: Cambridge University Press.

Ur, P. (1996). A course in language teaching: Practice and theory. Cambridge: Cambridge University Press.

Wrembel, M. (2001). Innovative approaches to the teaching of practical phonetics. Retrieved from http://www.phon.ucl.ac.uk/home/johnm/ptlc2001/pdf/wrembel.pdf

Zemanova, S. (2007). Teaching English pronunciation to adult learners. Diploma thesis, University of Masaryk.

Zielinski, B. W. (2008). The listener: No longer the silent partner in reduced intelligibility. System, 36, 69-84. http://dx.doi.org/10.1016/j.system.2007.11.004 
Afshari, S., \& Ketabi, S. 